\title{
Effect of Fertility Level, Plant Density and Age of Seedling on Transplanted Pearl Millet (Pennisetum glaucum)
}

\author{
Santosh Kumar Pandit ${ }^{1}$, Shambhu Prasad ${ }^{2}$, Mahesh Kumar Singh ${ }^{2}$, \\ Y.K. Singh ${ }^{3}$, Indrajeet Kumar Niranjan ${ }^{1}$ and Rakesh Kumar ${ }^{4 *}$ \\ Department of Agronomy, Bihar Agricultural University, \\ Sabour (Bhagalpur)-813210, Bihar, India \\ *Corresponding author
}

\begin{abstract}
A B S T R A C T
A field experiment was conducted during the kharif season of 2018 at the Research Farm, Bihar Agricultural University, Sabour, Bhagalpur, Bihar to find out the effect of fertility level, planting density and age of seedling on transplanted pearl millet under rainfed agroecosystem of South Bihar. Experiment was laid out in a factorial randomized block design and replicated thrice. The treatment comprised of three levels of fertility levels viz. $F_{1}(90$ : 45: $\left.45 \mathrm{~kg} \mathrm{NPK} \mathrm{ha}^{-1}\right), \mathrm{F}_{2}\left(120: 60: 60 \mathrm{~kg} \mathrm{NPK} \mathrm{h}^{-1}\right), \mathrm{F}_{3}\left(150: 75: 75 \mathrm{~kg} \mathrm{NPK} \mathrm{ha}^{-1}\right)$, four combinations of plant population and age of seedling i.e $\mathrm{T}_{1}(15$ days old seedling at 50 $\mathrm{cm} \times 20 \mathrm{~cm}$ ), $\mathrm{T}_{2}(15$ days old seedling at $50 \mathrm{~cm} \times 25 \mathrm{~cm}), \mathrm{T}_{3}(20$ Days old seedling at 50 $\mathrm{cm} \times 20 \mathrm{~cm})$ and $\mathrm{T}_{4}(20$ days old seedling at $50 \mathrm{~cm} \times 25 \mathrm{~cm})$. Results revealed that application of 150:75:75 kg NPK ha ${ }^{-1}$ was recorded significantly grain $\left(3.95 \mathrm{t} \mathrm{ha}^{-1}\right)$ but noted at par with 120:60:60 kg NPK ha ${ }^{-1}$. Among the levels of plant population and age of seedling, $\mathrm{T}_{3}$ treatment had significantly higher grain yield $\left(3.95 \mathrm{t} \mathrm{ha}^{-1}\right)$, net return (Rs.71788/ha) and B: C ratio (3.19) but being statistically similar with $\mathrm{T}_{1}$ treatment. Hence, it may be concluded that to achieving higher crop productivity yield, high yielding hybrids pearl millet cultivars could be grown with 120: 60: $60 \mathrm{~kg} \mathrm{NPK} \mathrm{ha}^{-1}$ under the planting geometry of $50 \mathrm{~cm} \times 20 \mathrm{~cm}$ for transplanting of 15 days old or 20 days old seedling for agro-ecosystem of South Bihar.
\end{abstract}

\section{Introduction}

Pearl millet (Pennisetum glaucum L.) popularly known as Bajra, cattle millet or bullrush millet is an important coarse grain cereal crop of arid and semi-arid regions of India (Ramesh et al., 2006). It ranks as $6^{\text {th }}$ most important food grains in world and sustaining one third of the world's population (Raily, 2006)). India is the largest producer of pearl millet in area $(7.12 \mathrm{~m}$ ha) and production $(8.06 \mathrm{mt})$ with productivity of $1132 \mathrm{~kg} \mathrm{ha}^{-1}$ (Anonymous, 2017). This crop is normally grown as rainfed crop with annual rainfall ranging from 150 to $600 \mathrm{~mm}$.

Thus, nutritional value of pearl millet (11-19 $\%$ protein, $60-78 \%$ carbohydrates and 3.0-4.6 $\%$ fats) offers much scope for development of value-added products in new health conscious 
consumers especially for diabetic and heart patients (Yadav et al., 2011). Pearl millet is generally grown on marginal lands having poor soil fertility of low input management. With the advancement of technology, many pearl millets hybrids are developed and that are responsive to fertilizers besides other good agronomic practices (Kumar et al., 2003). Balanced fertilization not only having yield advantages in pearl millet, also increases the quality of produce (Kumar et al., 2019). Nitrogen is a most vital nutrient and performs as a component of many organic compounds viz. proteins, amino acid, nucleotides, enzymes, protoplasm, vitamins, hormones, alkaloids etc. It also enhances the utilization of phosphorus and potassium (Prakash et al., 2017)).

Application of nitrogen produces taller plant extending the harvesting period and improved quality of produce like protein and succulence. Phosphorus (P) is a leading limiting factor for plant growth and productivity (Prasad et al., 2017, Prakash et al., 2018) and improves root proliferation that promotes better nutrition of plant (Kumawat et al., 2015;Yadav et al., 2018). Whereas potassium activates a number of enzymes, including synthesis of carbohydrates, provides resistance to the disease and adverse environmental condition (Jeet et al., 2014; Kumar et al., 2018; Kumar et al., 2019). Hence, ensuring the nutritional securities in a given soil for enhancing the yield and yield attributing characters of crop is important factor under the rainfed agro-ecosystem. Plant population is one of the important factors for higher production that determines the optimum plant density. An optimum plant stand enhances the efficiency of pearl millet by exploiting growth factors, which ultimately influences the crop yields. Higher plant density generally increases plant population resulting into inter-crop competition thereby affecting yield but lowering plant density reduce yield drastically. Hence, optimum plant density is utmost to harness the maximum yield potential of crop. Age of seedling bears a great role in establishment of crop and to avoid the root injury shocks during process of transplanting. Keeping these things in view, the present experimentation was carried out.

\section{Materials and Methods}

Experiment was carried out during the kharif season of 2018 at the Crop Research Farm, Bihar Agricultural university, Sabour, Bhagalpur, which is located at located at the South of river Ganges $\left(25^{\circ} 23^{\prime} \mathrm{N}, 78^{\circ} 07^{\prime} \mathrm{E}\right.$ and $37.19 \mathrm{~m}$ amsl). Soil of the experimental field was sandy loam in texture, slightly alkaline in $\mathrm{pH}$ (7.6), low in availability of $\mathrm{N}(218.9 \mathrm{~kg}$ $\mathrm{ha}^{-1}$ ), medium in available $\mathrm{P}$ and medium in availability of K. Experiment was laid out in a factorial randomized block design with three replications and twelve treatment combinations, comprising three levels of fertilizer $F_{1}$ (90: $45: 45 \mathrm{~kg}$ NPK ha ${ }^{-1}$ ), $F_{2}$ (120: 60: $60 \mathrm{~kg}$ NPK ha $\left.{ }^{-1}\right), \mathrm{F}_{3}(150: 75: 75 \mathrm{~kg}$ NPK $\left.\mathrm{ha}^{-1}\right)$ and integrations of the plant population and age of seedling $\mathrm{T}_{1}(15$ days old seedling at $50 \times 20 \mathrm{~cm}), \mathrm{T}_{2}(15$ days old seedling at $50 \mathrm{~cm} \times 25 \mathrm{~cm}), \mathrm{T}_{3}(20$ days old seedling at $50 \times 20 \mathrm{~cm}$ ) and $\mathrm{T}_{4}(20$ days old seedling at $50 \times 25 \mathrm{~cm}$ ). Nitrogen application was done in three splits as per the treatments.

Application of $1 / 3^{\text {rd }}$ of $\mathrm{N}$, full dose of $\mathrm{P}_{2} \mathrm{O}_{5}$ and $\mathrm{K}_{2} \mathrm{O}$ were applied as a basal and remaining $1 / 3^{\text {rd }} \mathrm{N}$ knee high stage and $1 / 3^{\text {rd }} \mathrm{N}$ at panicle initiation stage respectively through Urea, DAP and MOP. As per treatment fertilizers were placed in furrows made by narrow spade (Kudali), at a depth of $5 \mathrm{~cm}$ and apart from the seed rows by side dressing. The urea, di-ammonium phosphate (DAP) and muriate of potash (MOP) were used as sources for nutrient elements. Full dose of nitrogen was applied in two equal splits i.e. half at sowing and half at three weeks after sowing. 
However, the doses (according to treatments) of phosphorus and potassium were applied as basal dressing at the time of sowing. One weeding was done manually at 35 days after sowing during to control weeds and facilitate the good aeration. For biometric observations five plants in net plot were randomly selected and tagged for recording the biometric observations at different stages of crop growth. However, for measuring dry matter accumulation, five plants from the border rows were randomly selected.

Yield attributes and yield were studied before and after harvesting as per investigation required. Crop was harvested when grains are hard enough with nearly 15-20 per cent moisture and plants showed physiological maturity. Harvesting was done by removing earheads first and cutting down the plant later from each plot separately. The earheads after harvesting were sun dried at the threshing floor. Threshing was done thereafter by beating earheads with sticks. The threshed grains were dried in sun to bring the moisture content to 12-14 per cent and then final weights were recorded. The gross return, net returns and benefit: cost ratio of different treatments were worked out on the basis of prevailing market prices. To test the significance, experimental data collected on various aspects of investigation on pearlmillet were statistically analysed with procedure described by Cochran and Cox (1967).

\section{Results and Discussion}

\section{Growth attributes}

Higher plant height $(236.9 \mathrm{~cm})$, leaf area index (3.9), dry matter accumulation (1235.6 $\mathrm{g} \mathrm{m}^{-2}$ ), tillers hill ${ }^{-1}$ (4.2) at harvest were observed under the fertility levels of $\mathrm{F}_{3}$ (150:75:75 kg NPK ha ${ }^{-1}$ ), but being statistically at par with $\mathrm{F}_{2}$ but superior (Table
1). Fertility level of $F_{3}\left(150: 75: 75 \mathrm{~kg} \mathrm{ha}^{-1}\right)$ gave higher tillers plant $^{-1}$ at all the crop growth stages i.e. at 30 DAT (7.09), 60 DAT (6.79) and harvest (4.21), which was statistically at par with $\mathrm{F}_{2}\left(120: 60: 60 \mathrm{~kg} \mathrm{ha}^{-1}\right)$ but superior over $F_{1}\left(90: 45: 45 \mathrm{~kg} \mathrm{ha}^{-1}\right)$.

This might be due to application of nitrogen enhances development of strong cell wall and therefore stiffer straw, which might be resulted into profuse tillering. Higher availability of NPK through balanced fertilization and production of growth promoting substances (Prasad et al., 2014; Kumar 2015). Application of nitrogen, phosphorous produces positive significant effect on growth parameters (Jhakar et al., 2011; Mishra et al., 2017). Balanced application of potassium along with $\mathrm{N}$ and $\mathrm{P}_{2} \mathrm{O}_{5}$ not only gave higher yield but also increases quality of economic produces. Plant population and age of seedling affected the growth of pearl millet.

Plant height (238.5) and leaf area index (4.1) was recorded maximum in $\mathrm{T}_{3}$ (20 days old seedling at $50 \times 20 \mathrm{~cm}$ ) but statistically at par with the treatment $T_{1}$. Significantly higher dry matter accumulation (DMA) recorded with treatment $\mathrm{T}_{3}$ (20 days old seedling at $50 \mathrm{~cm} \mathrm{x}$ $20 \mathrm{~cm}) 1260 \mathrm{~g} \mathrm{~m}^{-2}$, which was statistically at par with $\mathrm{T}_{1}$ (20 days old seedling at $50 \mathrm{~cm} \mathrm{x}$ $25 \mathrm{~m}$ ). Plant population and age of seedling affect the number of tillers plant ${ }^{-1}$.

Treatment $T_{2}$ produced significantly higher tillers plant ${ }^{-1}$, but statistically at par with $\mathrm{T}_{4}$, $\mathrm{T}_{3}$ at $30 \mathrm{DAT}, \mathrm{T}_{1} \& \mathrm{~T}_{4}$ at $60 \mathrm{DAT}$ and $\mathrm{T}_{4}$. Young seedlings recorded better root growth and facilitated the increased cell division/enlargement due to increased photosynthetic rate subsequently increasing plant height and number of tiller hill ${ }^{-1}$ (Kumar et al., 2017; Prasda et al., 2017). 
Table.1 Effect of fertility, plant population and age of seedling on growth parameters of pearl millet

\begin{tabular}{|c|c|c|c|c|}
\hline Treatment & Plant height (cm) & DMA (g) & LAI & Tillers hill $^{-1}$ (no.) \\
\hline \multicolumn{5}{|l|}{ Fertility level } \\
\hline $\mathbf{N}_{90} \mathbf{P}_{45} \mathbf{K}_{45}$ & 221.92 & 138.25 & 3.66 & 3.53 \\
\hline $\mathbf{N}_{120} \mathbf{P}_{60} \mathbf{K}_{60}$ & 232.83 & 150.98 & 3.76 & 3.93 \\
\hline $\mathbf{N}_{150} \mathbf{P}_{75} \mathbf{K}_{75}$ & 236.92 & 152.90 & 3.99 & 4.21 \\
\hline $\mathrm{CD}(\mathrm{P}=\mathbf{0 . 0 5})$ & 10.64 & 6.20 & 0.24 & 0.21 \\
\hline \multicolumn{5}{|c|}{ Plant population and seedling age } \\
\hline 15 DOS at $50 \mathrm{~cm} \times 20 \mathrm{~cm}$ & 234.44 & 137.72 & 3.88 & 3.80 \\
\hline 15 DOS at $50 \mathrm{~cm} \times 25 \mathrm{~cm}$ & 220.89 & 156.84 & 3.52 & 4.07 \\
\hline 20 DOS at $50 \mathrm{~cm} \times 20 \mathrm{~cm}$ & 238.56 & 140.57 & 4.07 & 3.73 \\
\hline 20 DOS at $50 \mathrm{~cm} \times 25 \mathrm{~cm}$ & 228.33 & 154.38 & 3.74 & 3.96 \\
\hline $\mathrm{CD}(\mathrm{P}=\mathbf{0 . 0 5})$ & 12.28 & 7.16 & 0.28 & 0.25 \\
\hline
\end{tabular}

Table.2 Effect of fertility, plant population and age of seedling on yield attribute of pearl millet

\begin{tabular}{|c|c|c|c|c|c|}
\hline Treatment & $\begin{array}{c}\text { Effective } \\
\text { tillers hill }^{-1} \\
\text { (no.) }\end{array}$ & $\begin{array}{c}\text { Ear head } \\
\mathbf{m}^{-2}(\text { no. })\end{array}$ & $\begin{array}{l}\text { Ear head } \\
\text { length }(\mathrm{cm})\end{array}$ & $\begin{array}{l}\text { Ear head } \\
\text { dia. }(\mathrm{cm})\end{array}$ & $\begin{array}{c}\text { Ear head } \\
\text { wt. (g) }\end{array}$ \\
\hline \multicolumn{6}{|l|}{ Fertility level } \\
\hline $\mathbf{N}_{90} \mathbf{P}_{45} \mathbf{K}_{45}$ & 1.8 & 15.8 & 25.1 & 3.4 & 51.6 \\
\hline $\mathbf{N}_{120} \mathbf{P}_{60} K_{60}$ & 1.9 & 16.6 & 26.4 & 3.6 & 57.5 \\
\hline $\mathbf{N}_{150} \mathbf{P}_{75} \mathbf{K}_{75}$ & $2 . q$ & 17.8 & 27.4 & 3.7 & 59.9 \\
\hline $\mathrm{CD}(\mathbf{P}=0.05)$ & 0.17 & 1.2 & 1.1 & 0.2 & 2.9 \\
\hline \multicolumn{6}{|c|}{ Plant population and seedling age } \\
\hline 15 DOS at $50 \mathrm{~cm} \times 20 \mathrm{~cm}$ & 1.8 & 17.1 & 25.8 & 3.5 & 54.4 \\
\hline 15 DOS at $50 \mathrm{~cm} \times 25 \mathrm{~cm}$ & 2.1 & 15.9 & 27.3 & 3.7 & 60.3 \\
\hline 20 DOS at $50 \mathrm{~cm} \times 20 \mathrm{~cm}$ & 1.8 & 17.7 & 25.5 & 3.4 & 53.3 \\
\hline 20 DOS at $50 \mathrm{~cm} \times 25 \mathrm{~cm}$ & 2.0 & 16.1 & 26.6 & 3.6 & 57.4 \\
\hline $\mathrm{CD}(\mathrm{P}=0.05)$ & 0.20 & 1.4 & 1.3 & 0.18 & 3.3 \\
\hline
\end{tabular}

Table.3 Effect of fertility, plant population and age of seedling on yield of pearl millet

\begin{tabular}{|c|c|c|c|}
\hline Treatment & Test wt. (g) & $\begin{array}{c}\text { Grain yield } \\
\left(\mathrm{t} \mathrm{ha}^{-1}\right)\end{array}$ & $\begin{array}{l}\text { Stover yield } \\
\left(\mathrm{t} \mathrm{ha}^{-1}\right)\end{array}$ \\
\hline \multicolumn{4}{|l|}{ Fertility level } \\
\hline $\mathbf{N}_{90} \mathbf{P}_{45} \mathbf{K}_{45}$ & 10.17 & 3.57 & 7.88 \\
\hline $\mathbf{N}_{120} \mathbf{P}_{60} K_{60}$ & 11.42 & 3.84 & 8.26 \\
\hline $\mathbf{N}_{150} \mathbf{P}_{75} \mathbf{K}_{75}$ & 12.17 & 3.95 & 8.37 \\
\hline $\mathrm{CD}(\mathbf{P}=0.05)$ & 0.96 & 0.21 & 0.37 \\
\hline \multicolumn{4}{|c|}{ Plant population and seedling age } \\
\hline 15 DOS at $50 \mathrm{~cm} \times 20 \mathrm{~cm}$ & 10.84 & 3.85 & 8.29 \\
\hline 15 DOS at $50 \mathrm{~cm} \times 25 \mathrm{~cm}$ & 12.16 & 3.62 & 7.88 \\
\hline 20 DOS at $50 \mathrm{~cm} \times 20 \mathrm{~cm}$ & 10.52 & 3.95 & 8.48 \\
\hline 20 DOS at $50 \mathrm{~cm} \times 25 \mathrm{~cm}$ & 11.50 & 3.73 & 8.04 \\
\hline $\mathrm{CD}(\mathrm{P}=0.05)$ & 1.11 & 024 & 0.43 \\
\hline
\end{tabular}


Table.4 Effect of fertility, plant population and age of seedling on economics of pearl millet

\begin{tabular}{|l|c|c|c|}
\hline \multicolumn{1}{|c|}{ Treatment } & $\begin{array}{c}\text { Gross return } \\
\text { (Rs.) }\end{array}$ & Net return (Rs.) & B:C Ratio \\
\hline Fertility level & \multicolumn{3}{|c|}{} \\
\hline $\mathbf{F}_{\mathbf{1}}\left(\mathbf{N}_{\mathbf{9 0}} \mathbf{P}_{\mathbf{4 5}} \mathbf{K}_{\mathbf{4 5}}\right)$ & 86012 & 64793 & 3.05 \\
\hline $\mathbf{F}_{\mathbf{2}}\left(\mathbf{N}_{\mathbf{1 2 0}} \mathbf{P}_{\mathbf{6 0}} \mathbf{K}_{\mathbf{6 0}}\right)$ & 91391 & 68939 & 3.07 \\
\hline $\mathbf{F}_{\mathbf{3}}\left(\mathbf{N}_{\mathbf{1 5 0}} \mathbf{P}_{\mathbf{7 5}} \mathbf{K}_{\mathbf{7 5}}\right)$ & 94149 & 70345 & 2.96 \\
\hline CD (P=0.05) & 4004 & 4004 & $\mathrm{NS}$ \\
\hline Plant population and seedling age & & & \\
\hline $\mathbf{1 5}$ DOS at 50cm x 20cm & 92315 & 69795 & 3.10 \\
\hline $\mathbf{1 5}$ DOS at 50cm x 25cm & 86660 & 64196 & 2.86 \\
\hline $\mathbf{2 0}$ DOS at 50cm x 20cm & 94307 & 71788 & 3.19 \\
\hline $\mathbf{T}_{\mathbf{4}}(\mathbf{2 0}$ DOS at 50cm x 25cm) & 88787 & 66322 & 2.96 \\
\hline CD $(\mathbf{P = 0 . 0 5 )}$ & 4624 & 4624 & 0.21 \\
\hline
\end{tabular}

Increase in plant height might be due to optimum population attributed to minimum intra-species competition, which might help in proper utilization of natural resources (Kumari et al., 2017; Singh at al.2017).

\section{Yield attributes}

Grain yield of pearl millet was mainly depending on yield attributing characters. Higher yield attributes in treatment may be due to balanced fertilization (Table 2). Thus, all the yield attributes improved and gave significant effect of nutrient application. Application of 150:75:75 kg NPK ha ${ }^{-1}$ produced significantly higher yield attributes. Higher effective tiller hill ${ }^{-1}$ (2.09), ear head $\mathrm{m}^{-}$ 2 (17.80), ear head length (27.34), ear head diameter (3.7), ear head weight (59.9 g) and test weight $(12.1 \mathrm{~g})$ were found with fertility level of $F_{3}\left(150: 75: 75 \mathrm{~kg} \mathrm{NPK} \mathrm{ha}{ }^{-1}\right)$, which was statistically at par with $F_{2}(120: 60: 60 \mathrm{~kg}$ NPK ha $\left.{ }^{-1}\right)$. Significantly higher pearl millet grain yield $\left(3.95 \mathrm{t} \mathrm{ha}^{-1}\right)$ recorded with $\mathrm{F}_{3}$ (150:75:75 $\left.\mathrm{kg} \mathrm{NPK} \mathrm{ha}^{-1}\right)$ and found at par to F2 treatment.

Application of fertilizer provides to grater and prolonged availability of the nutrient. Increase in grain and straw yields with enhanced $\mathrm{N}$ application could be ascribed to increases activity of cytokinin in plants, leads to increased cell-division/elongation which leads to better plant growth, dry-matter production and higher photosynthesis (Kumar et al., 2017b). Thus, an increase in N supply might have increased yield attributing characters which ultimately contributed to increase in yields.

Increased grain yields due to varying levels of nutrients have been reported by Bhuwa and Sharma (2015). Yield attributing traits viz. ear head weight, and test weight were significantly higher in wider spacing. In case of plant population and age of seedling, $\mathrm{T}_{2}$ (15 days old seedling at $50 \mathrm{~cm} \times 25 \mathrm{~cm}$ ) exhibited significantly higher values of yield attributing characters viz. ear head length $(27.3 \mathrm{~cm})$, ear head diameter $(3.7 \mathrm{~cm})$, ear head weight $(60.3 \mathrm{gm})$ and test weight $(14.3$ $\mathrm{gm})$ over $\mathrm{T}_{1}$ (15 days old seedling at $50 \times 20$ $\mathrm{cm})$ however, it was found at par with $\mathrm{T}_{4}(15$ days old seedling at $50 \times 20 \mathrm{~cm}$ ).

However, the treatment $T_{3}$ was recorded significantly higher head $\mathrm{m}^{-2}$ (17.7) over $\mathrm{T}_{2}$ (15.9) and $\mathrm{T}_{4}$ (16.2) but was at par with $\mathrm{T}_{1}$ (17.1). The treatment $\mathrm{T}_{3}$ was recorded significantly higher grain yield $\left(3.95 \mathrm{t} \mathrm{ha}^{-1}\right)$ (Table 3) and remained at par with $\mathrm{T}_{1}$ due to closure plant spacing occupied maximum 
number of plant than wider spacing. It might be attributed to transplanting of pearl millet at optimum spacing of $50 \mathrm{~cm}$ x $25 \mathrm{~cm}$ with 20 days old seedlings that had ability to establish quickly by absorbing root injury shocks and promoting development of seminal roots as well as favouring proper utilization of natural resources (Singh et al., 2013; Singh et al., 2017; Jeet et al., 2017).

\section{Economics}

Significantly higher gross return (Rs. $94149.34 \mathrm{ha}^{-1}$ ), net return (Rs. $70345 \mathrm{ha}^{-1}$ ) were recorded with $F_{3}$ (150:75:75 kg NPK ha ${ }^{1}$ ) and found at par to $F_{2}$ (Table 4). Highest gross return (Rs. $94307 \mathrm{ha}^{-1}$ ), net return (Rs.71788ha ${ }^{-1}$ ) and B: C ratio (3.19) were recorded with $\mathrm{T}_{3}$, which was statistically at par with $T_{1}$ but significant over $T_{2}$ and $\mathrm{T}_{4}$. This might be due to higher yield associated with the respective treatments (Kumar et al., 2015a,b; Kumar et al., 2017a,b; Kumar et al., 2016).

\section{References}

Anonymous.2017.AICRP on pearl millet, Pearl Millet News No.6.

Bhuva HM and Sharma S.2015.Influence of nutrient uptake by irrigation, nitrogen and phosphorous and their effect on quality parameters of rabi pearl millet. American-EURASIAN Journal of Agric. and Environ. Sci. 15(2):324-327.

Cochran, W.G. and Cox, G.M., Experimental Designs, Asia Publishing House, New Delhi, 1967.

Jakhar GR, Golada SL, Sadhu AC.2011.Influence of levels and time of application of nitrogen on growth, yield and nitrogen uptake by pearl millet during summer. Madras Agricultural Journal 98(10/12):347-349.

Jeet S, Singh JP and Kumar R.2017.Production potential and nutrient uptake of QPM hybrids as influenced by nitrogen and sulphur fertilization. Journal of AgriSearch 4 (1):27-30, http://dx.doi.org/10. 21921/jas.v4i1.7415

Jeet S, Singh JP, Kumar $\mathrm{R}$ and $\mathrm{Om}$ H.2014.Response of nitrogen and sulphur levels on productivity and profitability of QPM hybrid (Zea mays L.) under dryland condition of Eastern Uttar Pradesh. Indian Journal of Agricultural Sciences 84 (5):589-594.

Kumar B, Prasad S, Mandal D and Kumar R.2017a.Influence of integrated weed management practices on weed dynamics, productivity and nutrient uptake of rabi maize (Zea mays L.). International Journal of Current Microbiology and Applied Sciences 6 (4):1431-1440, https: //doi.org/10.20546/ijcmas.2017.604.175

Kumar M, Kumar R Rangnamei KL, Das A, Meena KL and Rajkhowa DJ.2019.Crop diversification for enhancing the productivity for food and nutritional security under the Eastern Himalayas. Indian Journal of Agricultural Sciences 89 (7): 1157-61.

Kumar R, Bohra JS, Kumawat N and Singh AK.2015b.Fodder yield, nutrient uptake and quality of baby corn (Zea mays L.) as influenced by NPKS and Zn fertilization. Research on Crops 16 (2) : 243-249, doi:10.5958/23487542.2015.00036.4

Kumar R, Bohra JS, Kumawat N, Kumar A, Kumari A and Singh AK.2016.Root growth, productivity and profitability of baby corn (Zea mays L.) as influenced by nutrition levels under irrigated ecosystem. Research on Crops 17 (1):41-46, doi: 10.5958/2348-7542. 2016.00008.5

Kumar R, Bohra JS, Kumawat N, Upadhyay PK and Singh AK. 2018. Effect of balanced fertilization on production, 
quality, energy use efficiency and soil health of baby corn (Zea mays). Indian Journal of Agricultural Sciences 88 (1): 28-34.

Kumar R, Bohra JS, Singh AK and Kumawat N.2015a. Productivity, profitability and nutrient-use efficiency of baby corn (Zea mays) as influenced of varying fertility levels. Indian Journal of Agronomy 60 (2): 285-290.

Kumar R, Kumawat N, Kumar S, Singh AK and Bohra JS.2017. Effect of NPKS and $\mathrm{Zn}$ fertilization on growth, yield and quality of baby corn-A Review. International Journal of Current Microbiology and Applied Sciences 6 (3):1392-1428, https://doi.org/10.20546/ijcmas .2017 .603 .161

Kumar R, Mishra JS, Dwivedi SK, Kumar R, Rao KK, Samal SK, Choubey AK and Bhatt BP.2017b. Nutrient uptake and content in sorghum cultivars (Sorghum bicolor L) under summer environment. Indian Journal of Plant Physiology 22 (3):309-315,DOI 10.1007/s $405 \quad 02$ 017-0306-Z

Kumar R, Mishra JS, Rao KK, Bhatt BP, Hazra KK, Hans $\mathrm{H}$ and Mondal S.2019.Sustainable intensification of rice fallows of Eastern India with suitable winter crop and appropriate crop establishment technique. Environmental Science and Pollution Research, https://doi.org/ 10.1007/s11356-019-06063-4

Kumar R.2015.Productivity, profitability and nutrient uptake of maize (Zea mays) as influenced by management practices in North- East India. Indian Journal of Agronomy 60 (2): 273-278.

Kumari CR, Shanthi P, Reddy S.2017.Effect of spacing and nitrogen levels on productivity of pearl millet in dryland regions. Journal Research ANGRAU 46(1):48-58.
Kumawat N, Singh RP, Kumar R, Yadav TP and Om H.2015. Effect integrated nutrient management on productivity, nutrient uptake and economics of rainfed pigeonpea (Cajanus cajan) and blackgram (Vigna mungo) intercropping system. Indian Journal of Agricultural Sciences 85 (2):171-176.

Mishra JS, Kumar R, Ravikumar S, Kumar R, Prakash V, Rao KK and Bhatt BP.2017.Production potential of improved grain sorghum cultivars (Sorghum bicolor) under staggered plantings in non-traditional areas of Eastern India. Indian Journal of Agronomy 62 (1):74-80.

Prakash V, Mishra JS, Kumar R, Kumar R, Kumar S, Dwivedi SK, Rao KK, and Bhatt BP.2017.Thermal utilization and heat use efficiency of sorghum cultivars in middle Indo-Gangetic Plains. Journal of Agrometeorology 19 (1):2933.

Prakash V, Singh AK, Kumar R, Rao KK, Kumar S, Dwivedi SK, Samal SK, Mishra JS and Bhatt BP.2018.Thermal regimes: The key of phenological dynamics and productivity of fababean (Vicia faba L.). Journal of Agrometeorology 20 (1):36-39.

Prasad S, Agrawal KK, Kumar R and Prakash V.2017.Heat unit requirement of wheat cultivars under varying thermal regimes at Jabalpur. Journal of Agrometeorology 19 (3): 283-285.

Prasad SK, Samota A, Singh MK, Verma SK.2014. Cultivars and nitrogen levels influence on yield attributes, yield and protein content of pearl millet under semi-arid condition of vindhyan region. The Ecoscan: Special Issue. VI:47-50.

Raily K.2006.Whole grain Millet (Graminae/Poaceae)

http/Chetday.bcpm Retrieved on 17June 200910Pp.

Reddy SBP, Madhuri KVN, Venkaiah K, 
Prathima T.2016. Effect of Nitrogen and Potassium on Yield and Quality of Pearl Millet (Pennisetum glaucum L.) International Journal of Agriculture Innovations and Research, 4(4):678681.

Singh D, Baghel RS, Rajput R L, Kushwah SS, Rawat GS.2017. Influence of seedling age and plant geometry on yield and uptake of nutrients in transplanted peralm illet under late sown condition. TECHNOFAME- A Journal of Multidisciplinary Advance Research 6(1):149-152.

Yadav OP, Rai KN, Khairwal IS, Rajpurohit
BS, Mahala RS.2011.Breeding pearl millet for arid zone of north western India: constraints, opportunities and approaches. All India coordinated pearl millet improvement project, Jodhpur, India. pp.28

Yadav RK, Kumawat N, Singh A, Tomar IS, Singh M, Morya J, Kumar R and Upadhyay PK. 2018.Bio-efficacy of new herbicides on weed dynamics, productivity and nutrient uptake in maize (Zea mays) under rainfed condition of Jhabua hills. Indian Journal of Agricultural Sciences 88 (7):1123-1128.

\section{How to cite this article:}

Santosh Kumar Pandit, Shambhu Prasad, Mahesh Kumar Singh, Y. K. Singh, Indrajeet Kumar Niranjan and Rakesh Kumar. 2020. Effect of Fertility Level, Plant Density and Age of Seedling on Transplanted Pearl Millet (Pennisetum glaucum). Int.J.Curr.Microbiol.App.Sci. 9(06): 11241131. doi: https://doi.org/10.20546/ijcmas.2020.906.139 